\title{
Diversity of harvestmen (Arachnida, Opiliones) in Parque da Onça Parda, southeastern Brazil
}

\author{
Leonardo P. A. Resende ${ }^{1}$, Ricardo Pinto-da-Rocha ${ }^{2} \&$ Cibele Bragagnolo ${ }^{2}$
}

1. Universidade Paulista, Av. Independência, 210, 18087-101, Éden, Sorocaba, SP, Brasil.

2. Departamento de Zoologia, Instituto de Biociências, Universidade de São Paulo, Caixa Postal 11.461, 05422-970, São Paulo, SP, Brasil. (Corresponding author, ricrocha@usp.br)

\begin{abstract}
The environment most diverse in harvestmen species is the Atlantic Forest of São Paulo. However, there remains a lack of studies regarding their communities in certain regions. Among these regions is one south of the Paranapiacaba mountain range in the state of São Paulo, the Parque da Onça Parda (POP). Through nocturnal collections and pitfall traps, the region's harvestmen community has been studied. The observed richness of this site included 27 species, with dominance of three species: Holcobunus nigripalpis Roewer, 1910, Neosadocus maximus (Giltay, 1928) and Munequita sp., accounting for $68.4 \%$ of harvestmen abundance. This makes the diversity of POP more similar to the semideciduous Atlantic Forest communities of the interior than to those of the Coastal Atlantic Forest that contains the park. Its geographic location places it within the Southern São Paulo State (SSP) area of endemism, along with the Parque Turístico do Alto Ribeira (PETAR), with which it shares up to $12 \%$ similarity regarding harvestmen fauna. Richness and abundance of harvestmen were positively related to temperature and humidity. The period of animal activity (as measured by abundance and richness) varied throughout the night, being highest in the early hours during both studied seasons (summer and winter).
\end{abstract}

KEYWORDS. Daddy longlegs, Alpha diversity, Atlantic Rain Forest.

RESUMO. O ambiente mais diverso em opiliões é a Mata Atlântica paulista, no entanto ainda há carência de estudos sobre suas comunidades em determinadas regiões; uma delas é o sul da Serra do Paranapiacaba no estado de São Paulo, onde está o Parque da Onça Parda (POP). Através de coleta noturna e montagem de armadilhas de queda, estudou-se a comunidade de opiliões da região. A riqueza do parque é de 27 espécies, porém a dominância de três espécies (Holcobunus nigripalpis Roewer, 1910; Neosadocus maximus (Giltay, 1928) e Munequita sp., que perfazem 68,4\% da abundância total de opiliões), torna a diversidade do POP mais semelhante com a região de Mata Atlântica Semidecídua do interior do que com as da Mata Atlântica Costeira, onde o parque está inserido. Sua localização geográfica o coloca dentro da área de endemismo do Sul de São Paulo (SSP), juntamente com o Parque Turístico do Alto Ribeira (PETAR) e Intervales, com quem possui uma semelhança na fauna de opiliões de $12 \%$. Os opiliões responderam aos parâmetros ambientais, com abundância e riqueza positivamente relacionadas à umidade e temperatura. Por fim, $o$ período de atividade desses animais (medida pela distribuição da abundância e da riqueza) parece ser bastante distinto ao longo da noite, sendo maiores nas primeiras horas, nas duas épocas do ano (verão e inverno).

PALAVRAS-CHAVE. Diversidade Alfa, Mata Atlântica, opiliões.

Harvestmen comprise the third most diverse order among the class Arachnida (over 6,000 species), being second only to mites and spiders (Shultz \& Pinto-DARоснA, 2007). The group is divided into four suborders: Cyphophthalmi, Dyspnoi, Eupnoi and Laniatores. Having a mainly pantropical distribution, Laniatores comprises the most diverse group with 3,500 species described (MACHADO et al., 2007).

Harvestmen are omnivores and can feed on other invertebrates, decaying plants and animals, as well as fungi. Yet there is a predominance of predatory habits (Bragagnolo \& Pinto-Da-Rocha, 2009). They can be found in most terrestrial ecosystems, but their greatest diversity is reported for tropical forests (PINTO-DARocha et al., 2005). The environment with greatest diversity of this group is the Atlantic Forest in São Paulo, where 232 species have been recorded (PINTO-DARochA, 1999). Apparently this occurs due to their being highly sensitive to environmental conditions, especially humidity (SAntos, 2007). Species richness declines at higher elevations in the tropics due to restrictions imposed by temperature and humidity (AlmEIDA-NeTO et al., 2006). Moreover, not only the diversity, but also the level of endemism is especially high in tropical forests, where several species present restricted distributions. For example, the Brazilian Atlantic forest harbors 600 of the nearly 6,000 described species of harvestmen in the world, of which around $97.5 \%$ are found exclusively in this biome (PINTO-DA-Rocha et al., 2005).

Studies of Atlantic harvestmen diversity began in the middle of the last century, when only lists of species were published, in which sampling protocols were not followed while collecting (for example SOARES 1944a,b,c,1945; SOARES \& SOARES, 1970). The standardization of sampling in harvestmen inventories began with PINTO-DA-RochA (1999). Sampling methodologies were best developed and used in subsequent work (Bragagnolo \& Pintoda-Rocha, 2003; Brescovit et al., 2004; Bragagnolo et al., 2007). Finally, the work of PINTO-DA-RochA et al. (2005) provides a detailed overview of the biological and geomorphological processes that formed the Atlantic rainforest itself, leading to the current spatial distribution of harvestmen within this biome. This work further determined areas of endemism of harvestmen and highlighed their high diversity.

The aim of this work is to analyze the harvestmen community in an Atlantic forest remnant (Parque da Onça Parda) and verify its temporal distribution throughout the night. A further aim is to investigate how the richness and abundance of these arachnids are affected by season (summer and winter) and environmental parameters (temperature and relative humidity). 


\section{MATERIAL AND METHODS}

Studied Area. Parque da Onça Parda (POP) is a Private Reserve of Natural Heritage ["Reserva Particular do Patrimônio Natural" (RPPN)], located in the municipality of São Miguel Arcanjo ( $24^{\circ} 05^{\prime} 01.89^{\prime}$ 'S, $48^{\circ} 00^{\prime} 57.58^{\prime \prime}$ ), state of São Paulo. The park area is made up of 50 ha covered with vegetation typical of the Coastal Atlantic Forest. It is part of the Paranapiacaba System, a prominent remnant of this biome with 150,000 ha located in the southern region of the state. However, the area had been subjected to logging during the 1940s and $1950 \mathrm{~s}$, and secondary vegetation predominates. POP is drained by the Monjolinho and Ribeirão Bonito Rivers, which belong to the Ribeira River basin. Average annual rainfall of the region is from 1,700 to $2,400 \mathrm{~mm}$, and average temperature is around $17-22^{\circ} \mathrm{C}$. According to Monteiro (1973) the Paulista Coastal Zone covering the park is inserted into a large South Coast climactic unit within the subtropical area, and is subjected to masses of tropical climates and polar fronts.

Sampling. Two nights of sampling were carried out in the summer (January 15-17, 2011), and two in the winter (July 22-24, 2010). During each night of sampling one area of the park was sampled (area 1, shore of Monjolinho stream, $24^{\circ} 04^{\prime} 45^{\prime \prime} \mathrm{S}-48^{\circ} 01^{\prime} 03^{\prime \prime} \mathrm{W}$; area 2 trail Onça-Mata Seca: $\left.24^{\circ} 05^{\prime} 07^{\prime \prime} \mathrm{S}-48^{\circ} 00^{\prime} 58^{\prime \prime} \mathrm{W}\right)$. Sites were chosen with no physiognomic differences between them. In each area, eight sampling points were selected independent of each other, and with a distance of at least 100 meters. Therefore, each point corresponded to a sampling unit. At each of these points, four transects were established $(10 \mathrm{~m} \times 30 \mathrm{~m}, 10 \mathrm{~m}$ apart from each other) and sampled by four collectors. At each transect, harvestmen that were found in litter, leaves and stems to a height of one meter, were collected and fixed in $70 \%$ ethanol. Thus, the total number of samples was 16 during each season, each sample being composed of four pseudoreplicates (standardized transects sampled by the same four collectors at all units). All sampling began at 6:00 pm and finished about 3:00 am, so that a temporal distribution analysis of harvestmen could be performed. Hourly temperature and relative humidity were measured with a digital thermohygrometer. In addition to nocturnal manual samplings, pitfall traps were assembled within the sampled areas. In total, 48 pitfall traps (made from PET bottles) were installed randomly in the spaces between transects. They were filled with $70 \%$ ethanol and covered by plastic plates on bamboo sticks to prevent entry of leaves and branches. These traps were installed nearly $5 \mathrm{~m}$ apart from each other, mounted on the first day of collection, and retrieved after 10 days.

Statistical analysis. Alpha diversity (mean diversity within the community) of POP harvestmen was determined by the Shannon - Wiener index $\left(H^{\prime}=\Sigma p i \ln \right.$ $p i)$; whereby $p i$ is the proportion of species in relation to the total number of individuals in the community, and $\ln$ is the natural logarithm or neperiane $\log (\approx 2.72)$. Conversion of Shannon index values for an effective number of species (value that represents the number of species if the community submits all species with equal abundance) was done using the formula: $\exp (\Sigma$ pi $\ln$ pi). This is the same as $\exp \left(H^{\prime}\right)$, whereby exp is the natural logarithm raised to In $H^{\prime}$ power, and $H^{\prime}$ is the value of Shannon index (Jost, 2006). To calculate beta diversity (the change in species composition between places) we used the Jaccard index $(\mathrm{Sj}=\mathrm{a} /(\mathrm{a}+\mathrm{b}+\mathrm{c}))$, which produced the dendrogram of similarity among localities based on data of present / absent species (MAgurRan, 1988). To assess the relationship between data (environmental parameters, temporal distribution of abundance, and richness of harvestmen), Multiple Linear Regression was used (relations between temperature, relative humidity, and richness and abundance), as well as linear correlation (temporal distribution of harvestmen - richness and abundance correlated with the nighttime hour). To evaluate the differences in abundance, richness and environmental parameters between seasons, ANOVA (Analysis of Variance) was used. These tests were developed in BioEstat 5.0 (Ayres et al., 2007).

\section{RESULTS AND DISCUSSION}

Environmental parameters. In winter the average temperature was $15^{\circ} \mathrm{C}(\mathrm{SD}: 1.041)$, and in summer $22^{\circ} \mathrm{C}$ (SD: 0.618). Relative humidity in winter showed a mean value of $85.5 \%$ (SD: 3.22 ). In summer, average relative humidity was $82.5 \%$ (SD: 2.75 ). Parameters varied little within the collection periods. However, between winter and summer there was a difference of $7{ }^{\circ} \mathrm{C}$ in average temperature $(\mathrm{F}=29.280, \mathrm{p}=0.005)$, and a marked variation in relative humidity $(\mathrm{F}=2.867 \mathrm{p}=0.051)$.

Richness. In total, 27 species of harvestmen were identified at POP belonging to two families and nine subfamilies (Tab. I). In total, five species were singletons and two were doubletons. Among Laniatores, only the Gonyleptidae species were collected. This is expected for a locality within the Atlantic Forest in São Paulo, a location in which this group represents 96\% of species in the suborder (KURY, 2003). Within this family, the subfamily Pachylinae was the most important, representing $48 \%$ of species. This result represented a dominance also expected for this group in the state of São Paulo, as Pachylinae accounts for $44 \%$ of the Gonyleptidae species (KuRY, 2003). Eupnoi Sclerosomatidae (subfamily Gagrellinae) was represented by two species (Holcobunus nigripalpis and Munequita sp.). The manual collecting method was most efficient, obtaining all the observed richness, as well as a higher number of individuals. Pitfall traps did not add any distinct species to those collected manually, and the number of individuals obtained was very low (Tab. I). In summer, 
Tab. I. Summary of harvestmen collected with two methods in two seasons at the Parque da Onça Parda São Miguel Arcanjo, state of São Paulo, Southeastern Brazil.

\begin{tabular}{|c|c|c|c|c|c|c|c|}
\hline \multirow{2}{*}{ Species } & \multicolumn{2}{|c|}{ Abundance } & \multicolumn{2}{|c|}{ Pitfall trap } & \multicolumn{2}{|c|}{ Manual collection } & \multirow[t]{2}{*}{ Total } \\
\hline & January & July & January & July & January & July & \\
\hline \multicolumn{8}{|l|}{ Suborder Laniatores } \\
\hline \multicolumn{8}{|l|}{ Family Gonyleptidae } \\
\hline \multicolumn{8}{|l|}{ Subfamily Caelopyginae } \\
\hline Ampheres leucopheus Soares \& Soares, 1948 & 0 & 4 & 0 & 0 & 0 & 4 & 4 \\
\hline \multicolumn{8}{|l|}{ Subfamily Goniosomatinae } \\
\hline Serracutisoma proximum (Mello-Leitão, 1922) & 12 & 13 & 0 & 0 & 12 & 13 & 25 \\
\hline \multicolumn{8}{|l|}{ Subfamily Gonyleptinae } \\
\hline Mischonyx parvus (Roewer, 1929) & 0 & 2 & 0 & 0 & 0 & 2 & 2 \\
\hline Mischonyx squalidus Bertkal, 1880 & 33 & 1 & 3 & 0 & 30 & 1 & 34 \\
\hline Neosadocus maximus (Giltay, 1928) & 177 & 133 & 5 & 1 & 172 & 132 & 310 \\
\hline Acanthogonyleptes sp. & 1 & 0 & 0 & 0 & 1 & 0 & 1 \\
\hline \multicolumn{8}{|l|}{ Subfamily Hernandariinae } \\
\hline $\begin{array}{l}\text { Pseudotrogulus pagu DaSilva \& Pinto- da-Rocha, } \\
2010\end{array}$ & 1 & 1 & 0 & 0 & 1 & 1 & 2 \\
\hline \multicolumn{8}{|l|}{ Subfamily Mitobatinae } \\
\hline Discocyrtoides nigricans (Mello-Leitão, 1922) & 8 & 2 & 0 & 0 & 8 & 2 & 10 \\
\hline Longiperna concolor (Mello-Leitão, 1923) & 8 & 0 & 0 & 0 & 8 & 0 & 8 \\
\hline Promitobates ornatus (Mello-Leitão, 1922) & 42 & 20 & 0 & 0 & 42 & 20 & 62 \\
\hline Promitobates trapista Bragagnolo \& Pinto-da-Rocha, 2012 & 7 & 2 & 1 & 0 & 6 & 2 & 9 \\
\hline \multicolumn{8}{|l|}{ Subfamily Pachylinae } \\
\hline Discocyrtus cornutus Piza, 1940 & 1 & 0 & 0 & 0 & 1 & 0 & 1 \\
\hline Discocyrtus goodnighti Soares \& Soares, 1945 & 5 & 1 & 0 & 0 & 5 & 1 & 6 \\
\hline Discocyrtus longicornis (Mello-Leitão, 1922) & 4 & 4 & 0 & 0 & 4 & 4 & 8 \\
\hline Discocyrtus sp. 1 & 1 & 0 & 0 & 0 & 1 & 0 & 1 \\
\hline Discocyrtus sp. 2 & 2 & 0 & 0 & 0 & 2 & 0 & 2 \\
\hline Eusarcus armatus Perty, 1833 & 0 & 1 & 0 & 0 & 0 & 1 & 1 \\
\hline Hypophyllonomus longipes Giltay, 1928 & 4 & 1 & 0 & 0 & 4 & 1 & 5 \\
\hline Hypophyllonomus maculipalpi (Piza, 1938) & 59 & 5 & 1 & 0 & 58 & 5 & 64 \\
\hline Hypophyllonomus sp. & 0 & 4 & 0 & 0 & 0 & 4 & 4 \\
\hline Rhioxyna zoppeii (Soares, 1944) & 1 & 0 & 0 & 0 & 1 & 0 & 1 \\
\hline Roeweria virescens (Mello-Leitão, 1940) & 24 & 35 & 0 & 0 & 24 & 35 & 59 \\
\hline Triglochinura apiaiensis Mello-Leitão, 1924 & 6 & 3 & 1 & 0 & 5 & 3 & 8 \\
\hline \multicolumn{8}{|l|}{ Subfamily Sodreaninae } \\
\hline Sodreana granulata (Mello-Leitão, 1922) & 3 & 0 & 0 & 0 & 3 & 0 & 3 \\
\hline \multicolumn{8}{|l|}{ Subfamily Tricommatinae } \\
\hline Pseudopachylus longipes Roewer, 1912 & 8 & 10 & 0 & 0 & 8 & 10 & 18 \\
\hline \multicolumn{8}{|l|}{ Suborder Eupnoi } \\
\hline \multicolumn{8}{|l|}{ Family Sclerosomatidae } \\
\hline \multicolumn{8}{|l|}{ Subfamily Gagrellinae } \\
\hline Holcobunus nigripalpis Roewer, 1910 & 635 & 16 & 3 & 0 & 632 & 16 & 651 \\
\hline Munequita sp. & 144 & 105 & 0 & 1 & 144 & 104 & 249 \\
\hline Total & 1186 & 363 & 14 & 2 & 1172 & 361 & 1544 \\
\hline
\end{tabular}


14 individuals representing six species were captured, while in winter only two individuals of two species were captured. Of the 48 traps set in winter, only two collected harvestmen, an efficiency of $4.16 \%$. Of the 48 traps set in summer, 12 collected harvestmen, representing an efficiency of $25 \%$.

Rarefaction curves showed different behavior between the two seasons (Fig. 1). Although both curves did not approach an asymptote, in winter the curve was steeper with no asymptotic trend (with half the number of individuals, 75 percent of richness had already been collected). In summer, the curve was less steep and an asymptotic trend could be observed (with half the number of individuals, more than 90 percent of richness had already been collected). More than twice the number of harvestmen was collected in the summer when compared to winter. Therefore, it is concluded that despite the large increase in abundance, richness of these animals did not increase in similar proportions between the two seasons of the year, and remained close to 20 species. Despite the small difference between total richness collected in the summer and winter, average richness in the two seasons was significantly different $(\mathrm{t}$ $=16.85, \mathrm{p}=0.0005$ ) (Fig. 2).

Abundance. During the winter, 536 individuals were collected (including 173 juveniles) belonging to 20 species; in summer 1,231 individuals were collected (including 45 juveniles), representing 23 species. There was a significant difference $(t=9.303, p=0.005)$ (Fig. 3) between the means of harvestmen collected in winter and summer. Distribution of harvestmen species abundances showed a notable difference between winter (Fig. 4) and summer (Fig. 5). In winter, the dominant species were Neosadocus maximus and Munequita sp., as both represented $44 \%$ of the total individuals collected. In summer, Holcobunus nigripalpis appeared as the dominant species, representing $51.5 \%$ of the total harvestmen collected. These three species together constituted $68.4 \%$ of all individuals collected during two seasons. According Bragagnolo et al. (2007), the abundance of Munequita sp. and Neosadocus maximus is not affected by quality of habitat nor fragment size of the forest in which they live. There are no published data on this subject for Holcobunus nigripalpis. However,

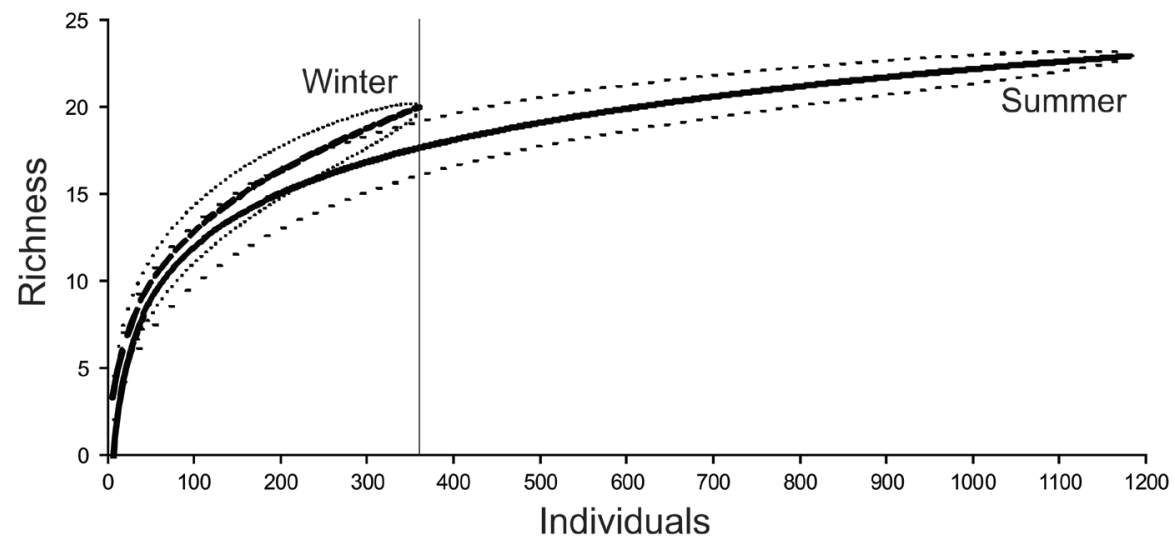

Fig. 1. Rarefaction curves of havestmen during winter (July 2010) and summer (January 2010), Parque da Onça Parda, São Miguel Arcanjo, state of São Paulo, southeastern Brazil.

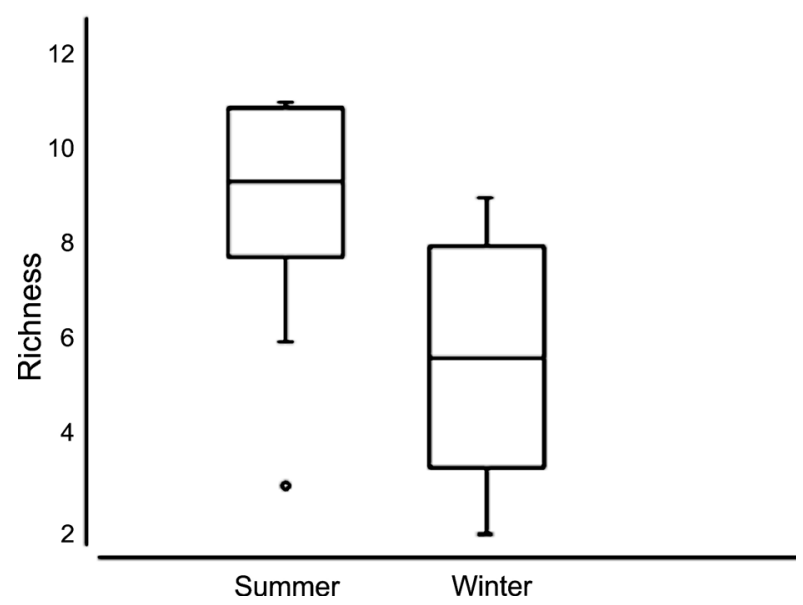

Fig. 2. Diferences among harvestmen richness during summer (January 2011) and winter (July 2010) at the Parque da Onça Parda, state of São Paulo, southeastern Brazil $(F=16.85 ; p=0.0005)$. Box show mean and standard deviation; whiskers indicate maximun and minimum.



Fig. 3. Diferences among harvestmen abundance during summer (January 2011) and winter (July 2010) at the Parque da Onça Parda, state of São Paulo, southeastern Brazil $(\mathrm{F}=9.303 ; \mathrm{p}=0.005)$. Box show mean and standard deviation; whiskers indicate maximun and minimum. 
according Bragagnolo et al. (2007) high dominance of a few Eupnoi species in a community can be associated with environments affected by high levels of human disturbance. The remaining species showed abundance more evenly distributed between the two seasons, with a small overall increase in summer. The less abundant species (represented by one or two individuals in the total sample) were Pseudotrogulus pagu, Eusarcus armatus, Acanthogonyleptes sp., Discocyrtus sp.1, D. sp. 2, D. cornutus, Rhioxyna zoppeii, and Mischonyx parvus.

Beta-diversity. PINTO-DA-Rocha et al. (2005) divided harvestmen fauna of the Atlantic Rain Forest into 12 areas of endemism (historically and geographically isolated locations that have an exclusive fauna). Due to the geographical position of the park, it is inserted into the endemic area of Southern São Paulo (SSP), together with the Parque Turístico do Alto Ribeira (PETAR) and Intervales. The diversity index of POP is $\mathrm{H}^{\prime}=1.84$, with a 6.32 diversity of species (effective number of species), far below the diversity occurring at other localities of the Atlantic Rain Forest (Tab. II). The most diverse location of harvestmen in the state of São Paulo is the
Estação Biológica do Alto da Serra de Paranapiacaba. With a richness of 46 species and a diversity of 19.86 , its richness is almost double the richness of POP (27 species), yet diversity is more than three times higher. The diversity of POP is closer to that of semi deciduous Atlantic Forest areas, like Serra do Japi (6.11). According to BRAGAGNOLO et al. (2007), communities of harvestmen are strongly affected by habitat fragmentation. In POP, the exploitation of wood for charcoal production within 50 years (the current vegetation is secondary) is probably the cause of low diversity. The beta diversity, represented by a dendrogram (Fig. 6), puts POP in a group with Cubatão Miracatu, Parque Estadual do Morro Grande, Estação Ecológica Juréia Itatins, Estação Biológica de Boracéia, Estação Biológica Serra de Paranapiacaba, and Parque Estadual Turístico do Alto Ribeira (PETAR). This is based on a similarity of approximately $12 \%$. Similarities between localities concerned mainly the distance between them, given the low dispersal ability of this group. Natural barriers, such as a chain of hills and mountains in the Serra do Mar, also greatly influence the isolation of the areas (PINTO-DA-RochA et al., 2005).

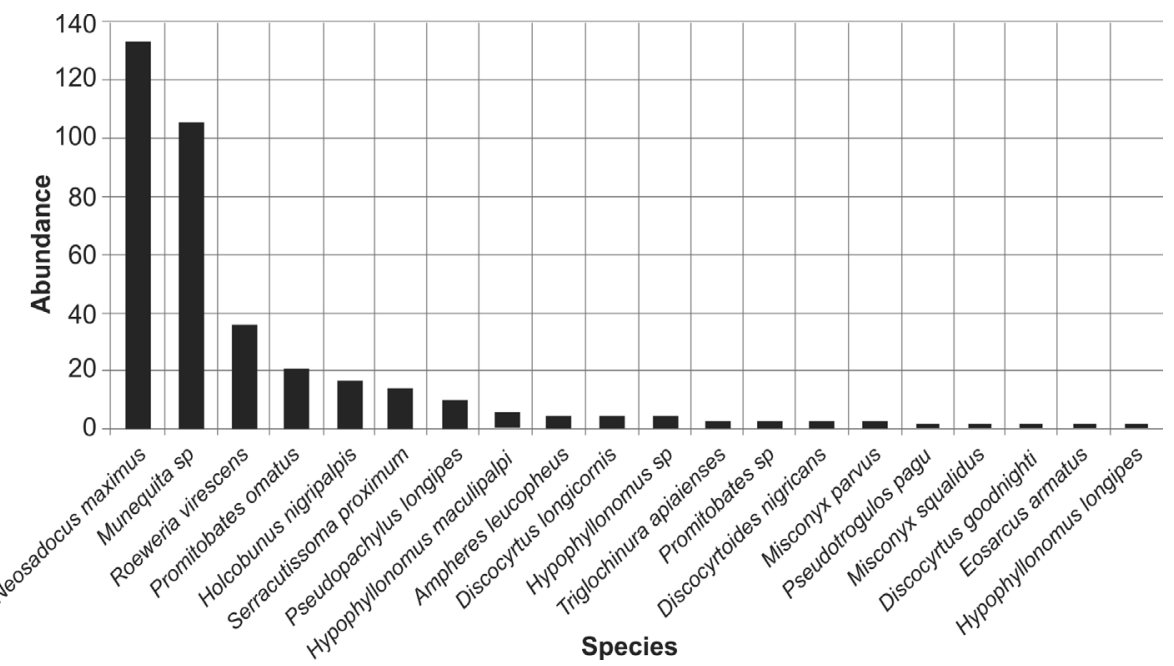

Fig. 4. Distribution of harvestmen of the Parque da Onça Parda São Miguel Arcanjo, state of São Paulo, southeastern Brazil during winter (July 2010).

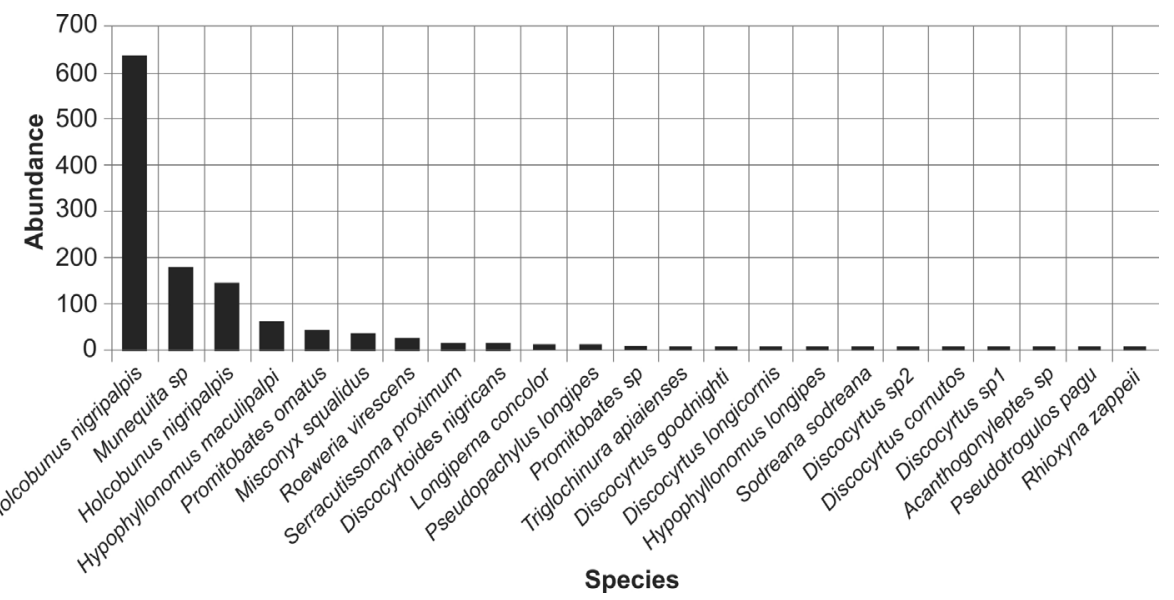

Fig. 5. Distribution of harvestmen of the Parque da Onça Parda São Miguel Arcanjo, state of São Paulo, southeastern Brazil during summer (January 2010). 
Tab. II. Comparison among alfa diversity in several quantitatively inventoried localities of Atlantic Rain Forest and one Amazonian (E.N.S*, Effective Number of Species; sources: BRAgagnolo et al., 2007 and PinTo-DA-Rocha \& Bonaldo, 2006) (RJ, state of Rio de Janeiro; SP, state of São Paulo; PA, state of Pará).

\begin{tabular}{lccccc}
\hline Name of locality & Samples/transects & Richness & Abundance & Shannon-Wiener & E. N. S* \\
\hline Parque Nacional Serra dos Órgãos (RJ) & 83 & 64 & 1194 & 3.053 & 21.178 \\
Est. B. Alto da Serra de Paranapiacaba (SP) & 60 & 46 & 729 & 2.989 & 19.865 \\
Miracatu (SP) & 49 & 25 & 497 & 2.272 & 9.698 \\
Parque Estadual Serra da Cantareira (SP) & 165 & 27 & 1138 & 2.272 & 9.698 \\
PETAR (SP) & 47 & 19 & 477 & 2.268 & 9.660 \\
Rio Juriti (PA) & 131 & 28 & 466 & 2.244 & 9.430 \\
Parque Estadual de Ilha Bela (SP) & 54 & 21 & 222 & 2.141 & 8.507 \\
Parque Nacional Serra da Bocaina (SP) & 40 & 21 & 251 & 2.091 & 8.093 \\
Parque Estadual de Ilha Anchieta, Ubatuba (SP) & 46 & 12 & 81 & 2.025 & 7.576 \\
Reserva Morro Grande (SP) & 192 & 34 & 2193 & 1.965 & 7.134 \\
Cubatão (SP) & 77 & 19 & 1.161 & 1.844 & 6.321 \\
Parque da Onça Parda (SP) & 128 & 27 & 1767 & 1.844 & 6.321 \\
Serra do Japi (SP) & 84 & 11 & 101 & 1.810 & 6.110 \\
\hline
\end{tabular}

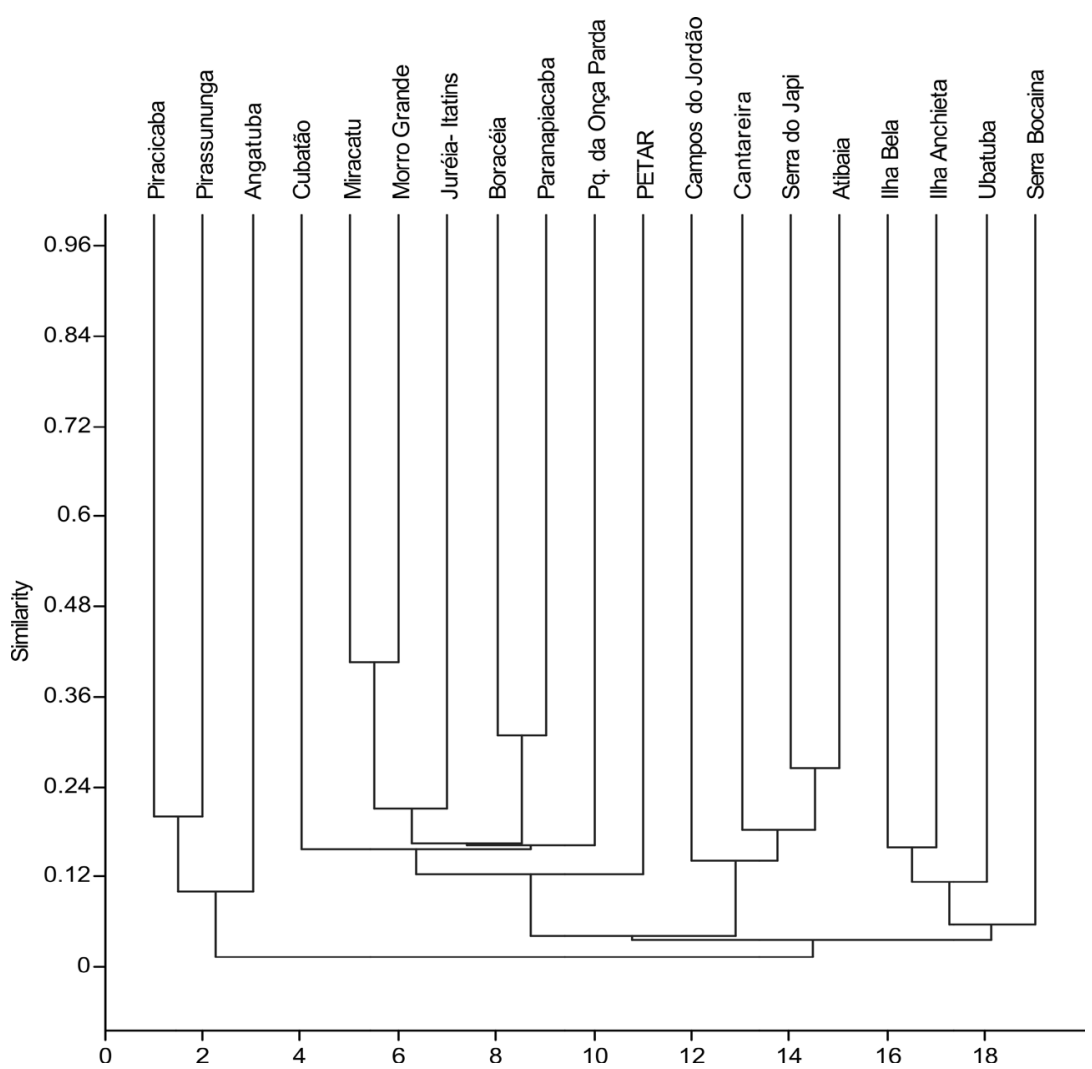

Fig. 6. Cluster analysis (Jaccard index 0.8858) among harvestmen fauna of 19 localities of the state of São Paulo.

Relation between abundance and richness with environmental parameters. Temperature and humidity are environmental factors that most influence the occurrence and habitat use by harvestmen (CURTIS $\&$ MACHADO, 2007). In summer, the abundance of harvestmen at POP correlated significantly with temperature $(\mathrm{p}=0.009)$ and relative humidity $(\mathrm{p}=0.04)$ $\left(\mathrm{r}^{2}=0.368, \mathrm{p}=0.019\right)$, increasing in warmer, moister environments. Richness was not associated with any of the parameters analyzed $\left(r^{2}=0.070, p=0.230\right)$. In winter the abundance of harvestmen was positively related to environmental parameters $\left(r^{2}=0.530 \mathrm{p}=\right.$ $0.003)$, temperature $(p=0.001)$, and relative humidity $(p=0.035)$, as more animals were collected during the greatest heat and humidity. Richness was also related to temperature $(\mathrm{p}=0.005)$ and relative humidity $(0.007)\left(r^{2}=0.490, p=0.004\right)$. Abundance decreased significantly over the period of activity (distribution of 
abundance over time) in summer. More animals were collected in the early hours of the evening than late at $\operatorname{night}(\mathrm{r}=0.649, \mathrm{p}=0.006)$. Richness in summer was not associated with period of activity $(\mathrm{r}=0.304, \mathrm{p}=0.251)$. In winter abundance and richness was correlated to the period of activity $(r=0.800, p=0.0001$ and $r=0.727$, $\mathrm{p}=0.001$, respectively), wherein fewer individuals and species were captured as nighttime advanced.

Harvestmen respond better to changes in temperature and humidity during the winter. Another important factor is that the richness of these animals is less susceptible to environmental changes than is their abundance. Finally, the activity of these animals (as measured by abundance and distribution of richness over time) seems to be very different throughout the night, both being higher in early nighttime hours during both seasons (except richness during summer).

Acknowledgements. We thank colleagues Alyson Ferreira, Uandrius Miziara, Bosco B. A. Resende and Fernando P. A. Resende for having helped in the collections of harvestmen. To Mr Marcel Pacano for giving the park to the survey. Dr. Mark R. Hara Montemor and Vivian (University of São Paulo) kindled helped identifying some harvestmen. Financial support from FAPESP financed processes 2008/06604-7; 2009/17206-5 and 2010/06253-0.

\section{REFERENCES}

Almeida-Neto, M.; Machado, G.; Pinto-da-Rocha, R. \& Giaretta, A. A. 2006. Harvestman (Arachnida: Opiliones) species distribution along three Neotropical elevational gradients: an alternative rescue effect to explain Rapoport's rule? Journal of Biogeography 33:361-375.

Ayres, M.; Ayres, Jr., M.; Ayres, D. L. \& SAntos, A. A. 2007. BioEstat: Aplicações estatísticas nas áreas das ciências biológicas e médicas. Belém, Sociedade Civil Mamirauá, MCT.

Bragagnolo, C. \& Pinto-Da-Rocha, R. 2003. Diversidade de opiliões no Parque Nacional da Serra dos Órgãos, Brasil. Biota Neotropica 3(1):1-18.

2009. Os opiliões. In: Lopes, M. I. M. S.; Kirizawa, M. \& Melo, M. M. R. F. eds. Patrimônio da Reserva Biológica do Alto da Serra de Paranapiacaba. A antiga Estação Biológica do Alto da Serra. São Paulo, Instituto de Botânica. p.525-536

Bragagnolo, C.; Nogueira, A. A.; Pinto-da-Rocha, R. \& Pardini, R. 2007. Harvestman in an Atlantic forest fragmented landscapes: Evaluating assemblage response to habitat quality and quantity. Biological Conservation 139:389-400.
Brescovit, A. D.; Bertani, R.; Pinto-da-Rocha, R. \& Rheims, C. A. 2004. Aracnídeos da Estação Ecológica de Juréia-Itatins (E. E. J. I.): inventário preliminar e dados sobre história natural (Arachnida). In: Marques, O.V.A. \& Duleba, W. eds. Ambiente, fauna e flora da Estação Ecológica Juréia/Itatins. Ribeirão Preto, Holos. p.196-219.

Curtis, D. J. \& Machado, G. 2007. Ecology. In: Pinto-da-Rocha, R.; Machado, G. \& Giribet, G. eds. Harvestmen: the biology of Opiliones. Cambridge, Harvard University Press. p.280-308

JosT, L. 2006. Entropy and diversity. Opinion. Oikos 113:2.

KurY, A. B. 2003. Annotated catalogue of the Laniatores of the New World (Arachnida, Opiliones). Revista Iberica de Aracnología, vol. especial monográfico, 1:1-337.

Machado, G.; Pinto-Da-Rocha, R. \& Giribet, G. 2007. What are harvestmen? In: Pinto-da-Rocha, R.; Machado, G. \& Giribet, G. eds. Harvestmen: the biology of Opiliones. Cambridge, Harvard University Press. p.1-13

MagurRan, A. E. 1988. Ecological diversity and its measurement. Princeton, Princeton University Press. 192p.

MonteIro, C. A. F. 1973. A dinâmica climática e as chuvas do estado de São Paulo: estudo geográfico sob forma de atlas. São Paulo, Universidade de São Paulo/ Instituto de Geografia. 129p.

Pinto-Da-Rocha, R. 1999. Opiliones. In: Brandão, C. R. F.; Cancello, E. M. eds. Invertebrados Terrestres. vol. V. Biodiversidade do Estado de São Paulo. Síntese do conhecimento ao final do século XX. São Paulo, FAPESP. p. 35-44

Pinto-Da-Rocha, R. \& Bonaldo, A. B. 2006. A structured Inventory of Harvestmen (Arachnida, Opiliones) at Juruti River Plateau, State of Pará, Brazil. Revista Ibérica de Aracnologia 13:123-130.

Pinto-da-Rocha, R.; daSilva, M. B \& Bragagnolo, C. 2005. Faunistic similarity and historic biogeography of the harvestmen of southern and southeastern Atlantic Rain Forest of Brazil. Journal of Arachnology 33(2):290-299.

Santos, F. H. S. 2007. Ecophysiology. In: Pinto-da-Rocha, R.; Machado, G. \& Giribet, G. eds. Harvestmen: The Biology of Opiliones. Cambridge, Harvard University Press. p.473-488.

Shultz, J. W. \& Pinto-da-Rocha, R. 2007. Morphology and functional anatomy. In: Pinto-da-Rocha, R.; Machado, G. \& Giribet, G. eds. Harvestmen: the biology of Opiliones. Cambridge, Harvard University Press. p.14-61

Sotres, B. A. M. 1944a. Mais alguns opiliões de Boracéia. Papéis Avulsos do Departamento de Zoologia do Estado de S. Paulo 4(12):177-186.

1944b. Opiliões do Alto da Serra. Papéis Avulsos do Departamento de Zoologia do Estado de S. Paulo 4(16):221242.

. 1944c. Opiliões do Alto da Serra II. Papéis Avulsos do Departamento de Zoologia do Estado de S. Paulo 4(18):277302.

. 1945. Opiliões de Ubatuba coligidos pelo Sr. Alfredo Zoppei. Boletim da Indústria Animal 7(1-2):85-96.

Sotres, B. A. M. \& Soares, H. E. M. 1970. Opiliões de Itatiaia. Revista Brasileira de Biologia 34(4):599-614. 